\title{
BODIES IN LATE ROMANTICISM: TWO PERSPECTIVES
}

\author{
RAMONA SIMUT,
}

\author{
Emanuel University, Oradea, Romania
}

\begin{abstract}
One of the major themes of discussion in the art and especially the literature of the 18th and 19th centuries was the body rather than the soul. In the beginning this seemed to be the case mostly because of the natural processes related to the transforming events of maturation and death of the human body and mind. However, towards the end of the 18th century and well into the 19th century, a certain shift took place from the common perspective on the body to a rather scientific literary approach. Our attempt is to notice and make the necessary connections between the concepts of nature (both human and external/physical nature) and the innovative technologies implemented in the then society, with a later reference to the new accidental and commercial facets of death felt as destruction of nature especially in the work of the American Romantic writers Ralph Waldo Emerson and Henry David Thoreau. Being aware that they are highly spoken of in view of their transcendentalism as a particular philosophy dealing with the bond between man and nature, we will slowly come to terms with this type of concerns and connect them to the conflicting reality of industrialization as a sudden and repressive phenomenon within the society of men. Finally our point is that this very phenomenon caused the two writers to make a historical detour and use their formation as naturalist thinkers in order to make sense of their century's deaths and diseases. This is to say that even from a Romantic perspective, the concern for the body is surprisingly concrete, while these writers' transcendentalist concerns for the soul are prolix though without substance.
\end{abstract}

KEYWORDS: body, accident, consumption, death, transcendentalism

\section{Introduction and Hypothesis}

From a Romantic perspective, the signs of progress in the 18th century were perceived as unequivocal ways to destroy human personality and discard it from history. This perception is due to the fact that the attack which the mechanisms related to the then new inventions brought upon man was sudden and eclipsed the soul with the shadow of a violent and accidental death. Their cause is well portrayed in Nietzsche's aphorisms, for instance, where he staunchly resents a future like that envisioned and supported by

* RAMONA SIMUT, (PhD 2010, Utrecht University, the Netherlands) is Reader in Comparative Literature and Literary Theory at Emanuel University, Oradea, Romania. E-mail: ramona.simut@emanuel.ro. 
Martin Heidegger with regard to the relationship between man and machine. On the other hand, Romantic writers in the 19th century looked at the diseases of their time from a totally different angle, aware that some of them were indeed new and had a consumptive nature. As this was the case with tuberculosis, the Romantics would not speak of it as being denigratory or regressive in a scientific manner, but thought of it as a means for spiritual and intellectual progress with a purgatory and reparatory purpose, all this in the midst of the industrial colossus. Thus, the failure pertains to the machine, which can sweep away the flesh, and not to the intellect or the soul, which in this case is always a step behind in matters of material productivity.

The differences between the 18th and 19th centuries Romantic writers consists in their respective view on the main death agents: the latter were faced with both the element of surprise and the urge to accommodate to the new death agents first in their own homes, and then all around them. It should be stressed, however, that the surprise is always the prerogative of the technique, while a repressive disease is smoothly accepted as an accessory to human existence. Though it is as old as the 18th century, sudden death has never had a solid logic as slow death had, and whatever modernity succeeded in this respect was to merely diversify the related terminology so it might become meaningful in the existentialist context. Moreover, in a Romantic work stressing the man-nature bond as a psychological and physical relationship, nature is a projection of the self, which in its absence remains without an object. Nowadays, that would be the case with the cultural meaning of man's travel to space or man being void of nature as we know it: man's displacement is considered a type of death, a divorce from nature in more than a symbolic way.

The surprisingly element related to death and its definition within Romantic literature and philosophy is the accidental, a term perceived as merely commercial, just like the causes of death: the windmill, the pit or coal mine, the first usage of vaccination in the 18th century or the new inventions of the 19th century industrialization. If we broaden this context to also comprise the 20th century, we could include the atomic bomb and space crafts. In the same time, the rituals associated with accidental deaths are from the very start commercial, a truism which today, at least, is universally accepted. Mourning, for instance, has become rapid and conscious, and its reward implies more materiality than humanity, an idea which launches and ends any Romantic fictional and non-fictional work (to exemplify, see Wordsworth, Charlotte Smith, Felicia Hemans, and Shelley's perception of and differentiation between imaginary and actual death, in Sandy 2016: 33, 61, 97).

Consequently, this paper will mainly notice the non-fictional work in a particular setting of the Romantic school, namely the 19th century Ameri- 
can Romantics whose oeuvre was strongly influenced by death with its personal and technical impression. As representative writers and theorists of American Romanticism, Ralph Waldo Emerson and Henry David Thoreau were surrounded by consumption (tuberculosis) all their life not only within their enlarged families, but wherever they went: 'The first known case in the Emerson family was that of Reverend William Emerson, Ralph Waldo's father, who had the disease when he died in 1811 at the age of 42[...]; all [his children] had symptoms of tuberculosis. Both Edward and Charles died of it in their late twenties [also the case of Waldo's first wife Ellen Tuckerthe "delicate flower" (Cooke 1902, 2: 16-17)—who died at 19. Waldo appeared to have symptoms of the disease at various times in his life, once writing of having a mouse gnawing at his chest, but died of an unrelated illness at age 79.' Also, 'Henry David Thoreau succumbed to tuberculosis at age of $44 \ldots$ His grandfather had died of it in 1801, and when Henry's father died in 1859 his symptoms were consistent with tuberculosis. His brother John was living with it... and their sister Helen became a victim in 1849 at age thirty-six' (Manoli-Skocay 2003). Death itself was the main reason why they even travelled to see other parts of the world and other cultures, thus to become Romantics.

The experiencing with death that Emerson and Thoreau came to acknowledge was a century old in Romantic literature, however they are among its few representatives who would associate the death of the body in its many shapes with the need for natural purity in the form of transcendentalism as the utopia of the soul in deadly bodies. It appears that they indeed grew fond of this specific New England form of a philosophy of the mind against the background of their families' health history. Consumption, however, was not the foremost accidental disease of their time, a reality reflected by their journals and memorialistic work; so were the pitfalls, windmills, coach travels on poor roads, horse riding, deep waters and suicide at the pressure of industrialization. Our aim is thus to identify consumption as a rather personal and communitarian disease causing a graceful and slow withering, while, on the other hand, the accidental deaths mentioned above trapped the body and instantly eliminated the mind, allowing the Romantics no time to adjust to it or lighten its shattering effect.

Though their literature is supposed to depict the personal thoughts of the two writers (who used to separate these diseases and specific deaths into different categories), what it describes is hardly subjective takes or variant of truth in their non-fictional work. One of the reasons why we chose to show aspects of deaths in their work was precisely the existence of factual documentation on their lives and historical details that illustrate a common fear of everything accidental both in Emerson and Thoreau's works, as well as in the minds of their contemporaries. 


\section{Emerson's Idea of Naturality. The Body in Odd Junctures}

Ralph Waldo Emerson (1803-1882) stands among the Romantics of his generation as a pioneer of a new type of taste for nature. In his essay Nature from 1836, Emerson challenges all lovers of nature to show some bone and review their relationship with the external elements individually. In this attempt, he believes, one must be able to tell nature's prerogatives from man's intrepid actions which can cause the world irreparable damage. Emerson sets to describe nature as a powerful force that transforms not only its own state and climate, but man's story, too, in that it surprises us with views and feelings which determine sensorial modulation in our mind and soul: 'Nature is a setting that fits equally well a comic or a mourning piece. In good health, the air is a cordial of incredible virtue. Crossing a bare common, in snow puddles, at twilight, under a clouded sky, without having in my thoughts any occurrence of special good fortune, I have enjoyed a perfect exhilaration. Almost I fear how glad I am' (RW Emerson 1836: 12).

When Emerson expounds how nature 'fits' both a benevolent and a negative state of mind, he rather asserts that man cannot do anything to supersede nature or in any way overrun natural law, by this showing just how much he borrows from Hegel's idealism in that he staunchly believes in the reality of the idea of nature, thus he also admittedly supports the individual's immediate intuition of divinity' (Vannatta and Vannatta 2010: 101). Unlike his fellow European or British Romantic writers, who also believed in the autonomy, authenticity and ascendancy of nature, Emerson seems to walk in the footsteps of those mild pre-Romantics and Classics when he describes this special type of liaison between what is of nature and what belongs to man. He however does not suggest, as his predecessors did, that man should overcome the powers of nature or that he could masterfully force his own feelings and will on nature. In the 18th century, for instance, Oliver Goldsmith was considered a pre-romantic writer who made the smooth transition from the classics' ideal of man-nature relationship as a governed milieu to the romantics' suffocating 'yearn' for nature (see Hauser 1999, III: 60 fwd.) in the midst of corporeal deterioration.

As a parenthesis here, it has to be said that not all Romantic writers in the 18th and 19th centuries were fascinated with nature as a kind of uncanny realm where the soul is transported in order to escape its dreary continuance in this world. To be sure, John Keats is a proper example in the long list of English Romantic poets for whom nature is indeed a hiding place due to its curative, therapeutic capacities. Nevertheless, there is also a lot of interest today in Keats' medical training, which is supported by such references in his biography and also his poetical testimony (see, for instance, $A$ Song about Myself or The Fall of Hyperion: a Dream) which only speaks for his passion for the materiality of the body, as he is the 'Poet-Physician' (see Al- 
lard, 2016: 87 fwd. and esp. chapter 4, 'Shap'd and Palpable': Keats and the Poet's Body). In the same tone, Emerson himself is a transcendentalist thinker educated at Harvard who, in the very introduction of his Nature book shows that his Romantically modeled century should renounce its retroactivity which, with all its 'biographies, histories, and criticism, [...] builds the sepulchers of the fathers'; instead, Emerson clarifies, it should create a 'poetry and philosophy of insight and not of tradition, and a religion by revelation to us, and not the history of theirs' (RW Emerson 1836: 5).

It seems as if for Emerson everything becomes personal as soon as he leaves his room and finds solace into the woods, which is the dominant place of revelation, since one has to be emerged into nature, this big picture that inundates us, and like a child see it with pure eyes, not the adult eyes. This personal revelation, to be sure-as personal nature, personal stars, personal sun and personal wilderness-depicts a landscapist reality comprising everything that is 'Not Me'; it is, consequently, everything outside the soul, 'both nature and art, all other men and my own body... ranked under this name, Nature' (RW Emerson 1836: 7). Emerson' transcendentalism is from one end to the other a perpetual amazement at this landscape offered by a body of things, be it of men or the stars, the constant marvel at the embodied idea. His idea of Nature is individualistic as it does not duplicate another's experience with nature; on the contrary, it knows its unicity which, for instance, 'distinguishes the stick of timber of the wood-cutter from the tree of the poet' (RW Emerson 1836: 10).

However, neither man (the Soul) nor Nature seem to have the upper hand, since Nature only 'fits' a man's state, while man only enjoys what nature brings with. There is, however, a special spot in which nature is believed to work its magic on man, in the sense that it changes man's state of mind and revives his body and soul:

In the woods, a man casts off his years and... is always a child. In the woods is perpetual youth. Within these plantations of God, a decorum and sanctity reign, a perennial festival is dressed... In the woods, we return to reason and faith. There I feel that nothing can befall me in life-no disgrace, no calamity, which nature cannot repair'... [In the woods] the name of the nearest friend sounds foreign and accidental (RW Emerson 1836: 12, 13).

Faithful to his theory that nature and man are individually part of the transcendental being of God, and that God is not himself a unity, but an oikonomy/economy (i.e. he is not merely one, but many in multiple manifestations), Emerson first rebels against his religious heritage as a unitarian Christian, and then plunges into the deep waters of natural theism, also known from the Antiquity and the Classics as polytheism or divine substance spread in each of nature's particular elements. He begins to sound 
more and more classical as he makes further comments about the necessity that man be moral as nature's actions are virtuous and thus beautiful. Hence his natural aestheticism as well.

On these grounds, Emerson states that all heroic individual actions manifest virtue because they maintain universal balance, and since the universe is all we can find deep inside ourselves, nothing we do should harm nature, otherwise we are suicidal. Emerson's idea is that heroic (human) action is not to be understood as bravery, but as an act of making good and meaningful sense of our innocence. Everything contrary to this strife for purity is contrary to nature, to human nature that is, and thus it is the opposite of reason and faith. This uncommon thinking for a Romantic writer is due to Emerson's transcendentalism which gives us a close up into his life and work unevenly molded in comparison with his fellow 19th century Romantic writers (see Morse 1987, especially chapters 3 and 4 on Poe, Thoreau, and Whitman), whose aim was to cause exceptions and not to attain the state of personal inner and external progress, in good terms with the universe around us (for an articulation of this idea in Emerson's biography and bibliography, see Ballanthyne 2005: 30; also Richardson 1995: 485 ff).

While not so inclined towards technical details as his fellow Henry David Thoreau was in observing nature, Emerson is nevertheless prone to gathering physical data which help him understand nature in its raw form, that is the rawest (purest), the better. Nonetheless, this does not affect the meaningful purpose of what is natural, hence we can only assume that by definition everything unnatural lacks proper reason and equilibrium. Even the loss of his brothers, his first wife and his first born Emerson thought of as natural, because their fading away was gracious, slow, communitarian, and perhaps they all reminded him that everything under the sun will eventually fade away. This is, perhaps, the epitome of Emerson's transcendentalism, which began in the midst of physical death in the first place, and received its special formulation according to this cycle of Nature.

Nevertheless, his Romantic spirit reacted in shock when, in one special situation, the unnatural happened and it suddenly took away a dear friend in the most 'tragic' of ways: 'The death of Margaret Fuller when she was only forty was a shock to Emerson... Somehow, Margaret's death caught him unprepared and undefended. Her loss drove him off himself and made him intensely conscious of a side of life he usually tended to rush over. It is easier to call this conscience a sense of tragedy,... a sense that something was fundamentally wrong with the universe, an awareness of some elemental lack at the core of things...' (Richardson 1995: 486). A journalist, editor, and transcendentalist herself at the time of her death, Margaret Fuller surely outlived other cultivated and notable women of her time who died from consumption, for instance. But why her death only was a matter 
of tragedy for Emerson is a fair question. Why did he perceive its circumstances as unnatural and shocking? For a start, it was probably because Margaret's death in 1850 was caused by a shift in the natural order, by something which should never have happened to mankind. And indeed it was something bigger that one death, an event which foreshadowed the sink of the Titanic, the supreme naval incident that for several years changed the face of the world. But the shipwreck in which Margaret died was perceived as so remote from the natural order that people had to find a logic in building lighthouses before, and not after they erected impressively large ships. The tragedy of Margaret's death (extensively commented on at that time and beyond, see Rorer and Bradley, eds., 2010: 4) cannot be fully grasped, according to the then Romantic American philosophy, without examining the second personality, besides Emerson, who helped shape transcendentalism by relocating it from 'Nature' into the woods (see this debated in a shorter version of this paper in Simuț 2012: 247-252).

\section{Thoreau and the Individual Body Whose Death Defies the Universe}

Henry David Thoreau (1817-1862), a Harvard fellow himself, lived the life of a Romantic both in terms of his expenditures (which exceeded his income by far), and in terms of his confrontation with sickness and death (on Thoreau in the context of the Industrial Revolution, see Ballanthyne with a comprising study on his life and career, 2005: 150; for even more details, see his biography in Richardson 1986).

Reading Emerson's Nature as early as 1837 (as a common guest in the former's home and a real help to his wife and children, see Walker 1987), Thoreau was also passionate about Goethe and Latin classics like Virgil, an enthusiasm which drove him to scientifically explore the natives of North America and their virgin land (Richardson 1986: 1-15). He was equally concerned, as Emerson was, with the innocence of heart and mind, which is one of the reasons why he wrote Walden (Thoreau 1950), and why he wrote it in the woods. But in Thoreau, the soul does not enter its state of wellbeing until its demand for morality and 'right' is met and protected by civil government. For what is worth, Thoreau himself felt that he was compelled to retrieve into the woods in order to write and, as he said, "to live deliberately, to front only the essential facts of life, and see if I could not learn what it had to teach, and not, when I came to die, discover that I had not lived' (Thoreau 1950: 118). To resume, Thoreau's literature cannot be fully grasped without his philosophical system, also known as his transcendental philosophy and naturalist ideology, which just like Emerson's is imbued with an utopian vision of body and nature (see a very informed analysis of Thoreau's perspective on life and world in Tauber 2001). For Thoreau, it seems, the result of new experiments and industrial inventions is commen- 
surate with the magnitude of natural disasters and calamities, and both realities are met with the reaction that a Romantic writer is capable of in times of distress.

Many critics tried to grasp the emphasis that Romantic literature has on irreparable realities, but in what Thoreau is concerned, Leonard Neufeld best captured this meaning in his work The Economist: Henry Thoreau and Enterprise (1989), where he speaks of two kinds of human natures: 'Thoreau is awake and alert; his neighbors are stagnant, asleep, little better than dead... One of his most common accusations is that ordinary men are dead in life, or they might as well be dead, or they are incapable of dying because they have not lived. Thoreau's romantic "half in love" with death deserves study' (see Neufeld in Turner, ed., 2009: 4, 34). However, Thoreau behaves like the classics when he uses his skills to observe the inner life of nature in the same habitat where purity and beauty are to be found, namely in the woods. In this respect, Thoreau is a follower of Goethe, who used to say, in a nutshell, that 'we are pantheists by searching nature, polytheists as poets, and ethically monotheists' (this was, to be sure, Goethe's 'affair' with nature as a poet, see Livescu 1984).

The relationship between sentiment and contemplation in Thoreau's Walden and his Journal is particularly important, since it shows that he thinks like a classicist whose feelings spring from the observation of natural complexity and form. In other words, this binary relationship is what is called 'Thoreau's juxtaposition of his metaphysical musing with the scientific knowledge that triggered the excitement' (Tauber 2001: 145). Whatever triggered the excitement was the form, which ultimately drives man to reassess his bond with nature: 'How was it when the youth first discovered fishes? [...] [What interested] mankind in the fish, the inhabitant of the water?[...] A faint recognition of a living contemporary, a provoking mystery' (Thoreau 1906: 11, 360). The conscious nature of this bond with nature expressed in the tenth part of Thoreau's Journal from 1858 comes through observation and contemplation only, as the mystery or the divine is peculiar to all natural things.

Consequently, Thoreau's transcendentalism comprises not only natural, brute elements, but also areas where civilization has been installed and became traditional in our civil society. His naturalist taste is nevertheless obstructed by civil order, in which Thoreau cannot find the same natural order displayed by the universe, hence his mistrust in the ranks of power and human standards that breach natural laws. Thus, in his essay 'On the Duty of Civil Disobedience', sometimes placed as an appendix to Walden (and shortly after its public delivery published under the title 'Resistance to Civil Government'), Thoreau extensively comments on the peculiarities of the American government, which 'has not the vitality and force of a single 
living man..., it is a sort of wooden gun to the people themselves. But it is not the less necessary for this...; for the people must have some complicated machinery... to satisfy that idea of government which they have' (Thoreau in Peabody, ed., 1849: 189).

It is rather clear that Thoreau's idea of 'naturality' is not applicable to the state, and his transcendentalism is not an all-embracing concept. Since man cannot enact his free and moral state into social laws, Thoreau thinks, and since all law is a product of state technicalities, man as individual must oppose whatever 'does not keep the country free and... does not educate' (Thoreau in Waldo, ed., 1919: 71; also Thoreau in Peabody, ed., 1849: 189). As a Romantic writer, Thoreau stands in awe at what 'the people' come to enforce as right and wrong or worthy of respect, which is in sharp contrast with the conscience that the individual uses to decide on civil matters. Disobeying the civil order regards extensively the law of men and the intricate and foremost corrupt structure of their government, but also the things that today's men praise as innovative and bountiful. In this respect, Emerson and Thoreau have their own special place within American Romanticism as they come from Concord, Massachusetts, an expanding commercial route and a promising industrial hub in their time.

Emerson and Thoreau had much to see and in part repel in the dawn of their modern era, facts of life which to their natural mind seemed disruptive. Every day the two writers would witness the forceful power of industrialization on their once beautiful town, and also people being proud of their achievements:

A lead pipe manufactory was set up in 1819 , a shoe factory was built in $1821 \ldots$, a group of entrepreneurs had set up the Milldam company in 1821, developing thereby a new commercial district in the center of town..., and the town was also a center for the manufacture of pencils, clocks, hats, bellows, guns, bricks, barrels, and soap... Wagons rumbled through town continually on roads that were both dusty and noisy. Concord was a busy transport hub and its numerous taverns were full of teamsters. It had six warehouses, a bindery, two saw mills, two grist mills, and a large five-story cotton mill (Richardson 1986: 15).

Thoreau's retreat in the woods for two years before commencing any civil or educational duties and at the peak of the industrial development of his homeland was an act of conscience directed towards his fellow citizens, as well as an act of self-instruction and observation. However, a devoted Romantic spirit would not go on with his retreat for too long: he is an effervescent spirit; he would rather re-enter society with new ideas and new brute forces so as to overturn and invalidate the existing order.

However, the fact that Thoreau does not advocate for a new government to replace the actual ruling, but for a better one instead, says a lot about his 
intentions as a citizen: he does not wish to abolish the present government, but to improve and educate it, which is as classical a method as it can be. Thoreau and Emerson alike were not the type of Romantics that would constantly complain about any kinds of inconveniences including their own fate and misunderstood genius, and they were mindful of the beneficial nature of progress.

As known, Emerson and Thoreau were loved by their fellow citizens and respected for their education, talent, and stamina manifested in spite of hardship in their life and their experience with consumption. They even had the conduct of admired Concordians, since Emerson was read by every cultivated American and gathered lots of cultivated men in his domestic philosophical circle, while Thoreau gave lectures for all audiences, which in turn considerably maximized his incomes (see, for details, RW Emerson 2004; Dean and Hoag 1996: 241-362; for Emerson's necrology, see Concord Freeman 1882). They were men of their time who did not oppose development, but given their family and friends' dreadful history with consumption, they were also men of prudence aware that their contemporaries could soon become men without bodies, meaning they were unable to fight death and disease with more machines and money right away. For them it was the machine that imposed on people and increased the unknown of the natural order by ever expanding the territory of man, thus exposing the body to further perils and diseases. For both Thoreau and Emerson, this exploration of the unknown creates an uneven relationship between the social and the moral, between industry and art, since the machines scout physical powers only.

\section{Conclusions}

In which the physical wellbeing is concerned, Emerson and Thoreau's fear of the unknown is unlikely to derive from universal forces, cataclysms and furies. This kind of the unknown has an observable source, which is the magnificence of nature and its raw material. These Romantics' fear is located deeply within the human habitat and was thought to be caused by people's search for instant progress and their alienation from nature and the inner self. The unknown which brings fear is not of the elements, which they rather welcome because they bring them the joy of research and discovery, the return to essence. Although, for instance, water would be an element which could instil fear, hindering him to adventure into its depths, man will instead respect and cherish the life embedded in it. This means that the larger universe comprises another, a microcosm from which life itself springs: 'In one of his last works [The Dispersion of Seeds]... [Thoreau] recounts having "leveled for an artificial pond at our new cemetery, Sleepy Hollow".' The pond was finally completed in 1859, and the following year 
sported 'several small patches of the large yellow and kalmiana lily', a fact which led him to remark, 'Thus, even in the midst of death, we are in life.' A few lines further we fid out that Thoreau loved to see how Nature was rife with life, and nowhere is the life of Nature so rife as in vernal pools. However, Thoreau also insisted that the "universe is wider than our views of it'; 'his woodland pools, spring-holes, and ditches are microcosms of that... universe in which energies are constantly transmuted one into another' (Rorer and Dean 2010: 3,4). The same image captured in the presence of the pond (see Walden pond) or at Sleepy Hollow, where life is created at the surface of waters as a microcosm is encountered under the water, and we already learned about Thoreau's passion for ichthyology in that he considers the fish as 'another image of God' (Tauber 2001: 145).

Either naturally created or handmade, ponds, ditches, and pools (which are water recipients) are not perceived as agents of death, at least not unwilling death. Deep waters are indeed to be feared, however murders in that realm and at that time were deemed as exceptional 'acts of God', while the voluntary action of suicide was considered common even in the most uncommon places (see, for details, Lonton 2008; Aiken 2009). Regarding the plagues which the Industrial Revolution helped spread, Lonton takes into consideration the varied causes of death in the 18th and 19th centuries especially in England, but they are broadly representative of all parts of the world. Such were the deaths induced by inoculation against smallpox and later on by tuberculosis, the pitfalls, bad roads, accidental drowning caused by lack of swim practice, free-lance horse riding, etc., all lowering the then average life span. As far as the body is concerned, and although the spirit may be forever young, those who died at sixty were thought to have died of old age. In this context, the sudden removal of the body in the 19th century through suicide was probably associated in a lesser degree with unrequited love and more with the rising 'pressure of industrialization' (Lonton 2008).

The innovative nature of medicine, commerce, manufacture, transportation, food and mine industry, and leisure were particularly exponential as causes of death in both the 18th and 19th centuries. They were the real unknown and unnatural factors which caused bereavement and uncertainty both physically and mentally, in spite of the progress they promised especially in the 19th century. They were feared more than cancer and heart failure both because they were everywhere in the news and they implied a foreign object that brought death instantly rather than slowly. Be it the inoculation formula against new infectious diseases such as smallpox (again, Lonton mentions this practice as common in England from as early as 1722, for instance, before the proper means of vaccination were even approved in 1796), which required many testing on real people, or the new windmills, coal pits, wagons or carts traveling with increasing speed, accidents at work, 
shipwreck or simply a horseback ride commonly practiced for leisure at the time, but which, without proper harness classes and skill, were perceived as unreliable, surprising, and sudden ways to produce death and suffering.

\section{References}

Aiken LR (2009) Dying, death, and bereavement. Fourth Edition. Mahwah, NJ: Lawrence Erlbaum.

Allard JR (2016) Romanticism, Medicine and the Poet's Body. New York, NY: Routledge.

Ballanthyne A (2005) Architecture theory: a reader in philosophy and culture. New York, NY: Continuum.

Concord's Irreparable Loss! The Death and Funeral of Ralph Waldo Emerson. Concord Freeman (May 4, 1882).

Cooke GW (1902) A Historical and Biographical Introduction to the Dial. Volume 2. Cleveland, $\mathrm{OH}$ : Rowfant Club.

Dean BP and Hoag RW (1996) Thoreau's Lectures After Walden: an Annotated Calendar. Studies in the American Renaissance 241-362.

Emerson EW (2004) Emerson in Concord. A Memoir Written for the Social Circle in Concord Massachusetts. Whitefish, MT: Kessinger.

Emerson RW (1836) Nature. Boston, MA: James Munroe and Company.

Hauser A (1999) The Social History of Art. Volume III, Rococo, Classicism and Romanticism. London and New York: Routledge.

Livescu J (1984) Preface to Johann Wolfgang von Goethe, Opere (Works). Volume 1. Bucharest: Univers.

Lonton T (2008) Vaccination, Windmills, and Other Causes of Death in 18th Century Whitkirk. Barwicker 92.

Manoli-Skocay C (2003) A Gentle Death: Tuberculosis in 19th Century Concord. The Concord Magazine.

Morse D (1987) American Romanticism. Volume I, From Cooper to Hawthorne. Excessive America. New York and London: Macmillan.

Oyebode F (ed) (2009) Mindreadings: Literature and Psychiatry. Glasgow: Bell and Bain.

Richardson RD (1995) Emerson. The Mind on Fire. Berkeley, CA: University of California Press.

Richardson RD (1986) Henry Thoreau: A Life of the Mind. Berkeley, CA: University of California Press.

Rorer A and Dean BP (eds) (2010) Of Woodland Pools, Spring-Holes and Ditches: Excerpts from the Journal of Henry David Thoreau. Berkeley, CA: Counterpoint.

Sandy M (2016) Romanticism, Memory, and Mourning. New York, NY: Routledge. 
Simuț R (2012) Death as Surprise in the Literature of 18th and 19th Centuries Romanticism. MJSS 3(7): 247-252.

Tauber AI (2001) Henry David Thoreau and the Moral Agency of Knowing. Berkeley, CA: University of California Press.

Thoreau HD (1906) Journal X (November 30, 1858). Boston, MA: Houghton Mifflin.

Thoreau HD (1849) Resistance to Civil Government. A Lecture Delivered in 1847. In Peabody EP (ed) Aesthetic Papers, pp. 189-213. New York, NY: G. P. Putnam.

Thoreau HD (1950) Walden. New York, NY: Harper.

Turner J (ed) (2009) A Political Companion to Henry David Thoreau. Lexington, KY: The University of Kentucky Press.

Vannatta J and Vannatta S (2010) Osler and Ralph Waldo Emerson: The Humanity of Medicine. In LaCombe MA and Elpern DJ (eds) Osler's Bedside Library, pp. 99-107. Philadelphia, PA: American College of Physicians.

Waldo RB (ed) (1919) Man or the State? New York, NY: B. W. Huebsch.

\section{Internet sources}

Walker M (1987) Dear Mr. Emerson. Nov. 29, Section 7, p. 24. https://www.nytimes.com/1987/11/29/books/dear-mr-emerson.html. Accessed in January 2019. 